\title{
ICT : Providing Sustainable Economic and Social Development in a Ubiquitous Network Society
}

${ }^{1}$ Ikharo A. B., ${ }^{2}$ Aliu D., ${ }^{3}$ Obasi C. C. and ${ }^{4}$ Okreghe C. O.

1,2,3,4 Department of Electrical and Computer Engineering, Edo University Iyamho, Edo State Nigeria

\begin{abstract}
Article Info

Volume 7, Issue 4

Page Number: 1-10

Publication Issue :

July-August-2020

\section{Article History}

Accepted : 01 July 2020

Published : 07 July 2020

The development of the traditional infrastructure of any country would facilitate and enhance information society. However, inadequate infrastructural development, poor economic and social access, slow adoption of new technology and limited technical know-how are some dilemma plaguing ICT application and implementation in the Nigeria context. This paper therefore, is poised toward addressing these issues and proffering recommendations with the aim of supporting government efforts, increasing the efficiency of social service delivery and raising economic efficiency and cost reduction in ICT related mechanism. It is hoped that ICT applications and usage would lead to systemic growth, economic development, and the provision of socio-economic sustainability in Nigeria.
\end{abstract}

Keywords : Infrastructure, Sustainability, Economic, Society, Development, Ubiquitous

\section{INTRODUCTION}

A significant perspective of infrastructural development is one of emerging issues in international community, nevertheless this still remains in conceptual schemes domicile in sustainable development among some developing countries of the world. The main reason may not be far fetch from the luminary style of high handedness of dishonesties in societal behaviour endeared by some of these developing nations. In the last decades, Nigeria has seen dramatic progress in telecommunication growth, notably in ICT infrastructure provision. But development progress has been far from uniform across the country, or across dimensions of human development. The past two decades has also witnessed a dramatic spread of information and communication technologies (ICTs) in developed countries resulting in the near ubiquitous presence of mobile telephony [20] and to a more extent the Internet and its supportive infrastructure. This technology has already changed many lives and hold the promise to greatly facilitate the achievement of a smart society. More than 500 billion Internet of Things (IoT) devices, from sensors, to actuators, to medical devices, will be connected to the internet by 2030 [26] and beyond, this will afford the Nigeria nation an opportunity to be proactive, invest and deploy ICT infrastructure for her economic and social benefits.

However, the need to really make this technology truly available, accessible, and affordable, can only be feasible if many of the technical, social, regulatory and legal issues are solved. According to [19], less than $10 \%$ of technical, economic and social problems of "what it will take to fully harness the power of ICT" 
relate to having a Personal Computer (PC) and it associative devices. The well known digital divide, comprising of infrastructure divide, access divide, literacy divide, language divide, information and knowledge access divide, jobs divide, health-care divide, entertainment divide and demographic divide are sustained problems within the ICT domain that need holistic and systematic approach. Too often, ICT infrastructure itself is thought of as a major profit centre with many private operators taking advantage on the users while making the applications and services unaffordable. The ICT sector is highly dynamic, and decades of very rapid growth in the capabilities of ICT components and networks have driven equally rapid innovation in technology and services [24]. By this, cities, nations and the entire world can become smart as a result of ICT adoption and usage.

The evolution of $4 G$ and $5 G$ is expected to facilitate advancement in health care system, people's culture, transportation system, educational system, trade, agriculture [26] and e.t.c. Their deployment would increase and enhance ICT expansion in a variety of forms such as increase the development of protective mechanism for persons and property management; smart control management and administration of vehicular traffic; saving electricity and solar energy with their deployment; measuring and evaluating the effects of environmental pollution and climate change; improving agricultural yield and establishing locations or sites for bumper harvest, and additionally, strategically leveraging government/private/farmer partnership in agricultural revolution; management of healthcare by streamless networks of dispensary supply and diagnostics expeditions, implementation of education without boarders -'online'; eliminating the dichotomy within cities and between cities and rural dwellers and the same time solving the problems emanating from them.

\section{LITERATURE REVIEW}

[23] posited that increased inflation, population and GDP per capita have negative effects on the number of Internet Users thereby affecting the economic growth of the country and recommended the Federal Government of Nigeria to enhance ICT in Nigeria for its economic growth which include enhanced funding and the development of an ICT masterplan for the Nigerian State.

In their paper [17] highlighted the main types of information and communication technologies (ICT) used in Nigeria, the challenges of using them, and provided an in-depth study of the social impacts of ICTs in Nigeria. We find that while some of these impacts are beneficial, others are pervasively detrimental to the society as a whole. Their overall finding showed that there is still a large scope of social benefits of ICTs yet to be explored in Nigeria. [18] examined some important imperative factors that sustain favourable social implications as well as critical factors that pander to unfavourable social implications of ICTs. The paper found out that core factors of social implications of ICTs were the Internet and other ICTs which facilitate development in developing countries and aid propagation of indigenous knowledge. It was found that ICTs do not induce unemployment in developing countries, nor promote social exclusion. They neither aid mass destruction of property nor induce organizational stress. It was also found that gender inequality and ethnicity/racism do not constitute challenges that affect social implications [12] had rightly said that Nigeria's past economic problems could be partly traced to lack of adequate telecommunications facilities required to support industrialisation and economic growth. Just as access to information and communication services is key to national development, when this access is lacking, national development is retarded. In terms of economic 
development, the incidence of low access to market sales, promotion and inflexible competition engulfing financial market, recurrent power outage and its poor distribution system for the industrial and consumer sectors needs and the lack of human-driven consumer-producer economy are some peculiar factors inhibiting the nation's economic emancipation. Similarly, in human development, the quality of life are a far cry, as access to education, health care, human capacity and facility are obviously contemptible for the teaming Nigeria populace. More so, many man-made, natural disasters are inadequately managed and indeed many lives are lost, land, plantations and communities are damaged and destroyed.

ICT can be a powerful tool to facilitate and enable affordable solutions to economic development, educational development, and social development in emerging economies and to those populations who are socio-economically deprived. Hence, this paper is poised to elucidate grey areas that ICT in an atmosphere of ubiquity technology would profit with a view to highlight key sectors needing Government attention.

\section{UBIQUITOUS NETWORK SOCIETY CONCEPT}

Ubiquitous technology is an evolving and encompassing phenomenon meaning computing technology which is invisible, entrenched into its environments and present everywhere. Ubiquitous network society is a society, where wireless data transfer and networking is possible for anyone, any place and whenever using different devices [10]. Ubiquitous technology is powered by computing power and is the cornerstone of any smart society. Yet the great paradox of the information society is the persistence of scarcity in a digital era of nearubiquitous and superabundant capabilities which remains a great challenge to the networked and developing economy and society.

In the ubiquitous information society information is expected to be available anytime and in everywhere. Ubiquitous development will have a significant impact on human work and everyday life. Development will lead to a society of spontaneous control, comprehensive knowledge and undying reminiscence without any one player being in total control of the development. In the ubiquitous society, making sense of what is real and what is virtual may become more and more difficult to differentiate and leaving a possibility of this differentiation not being important anymore. The main issue will be the ability to map the real world into the virtual world in a ubiquitous manner.

The scenarios on the right in Table 1 are the more progressed ubiquitous networking societies. According to [7], computing power demand will be drastically driven up by the underpinning technologies of a smart society, including Artificial Intelligence (AI), Internet of Things (IoT), blockchain, Augumented Reality/Virtual Reality (AR/VR), and that these technologies, as they become more mature, will help realize a large number of smart scenarios. Specifically, AI will turn autonomous driving, smart office, smart healthcare into reality; IoT will make smart firefighting, smart factory, smart agriculture and smart home possible; Blockchain will be used for digital certificate and information encryption; AR/VR will improve experience in smart malls, games and smart classrooms. Closely related to the issue of technology convergence and to fostering ubiquitous development in general is interoperability of different technologies. The advent of the promising $4 \mathrm{G}, 5 \mathrm{G}$ and the future $6 \mathrm{G}$ network technologies would put to rest the fair of complete migration to digital economy. 
Table 1 : Outline of the Ubiquitous/Smart Society Scenario

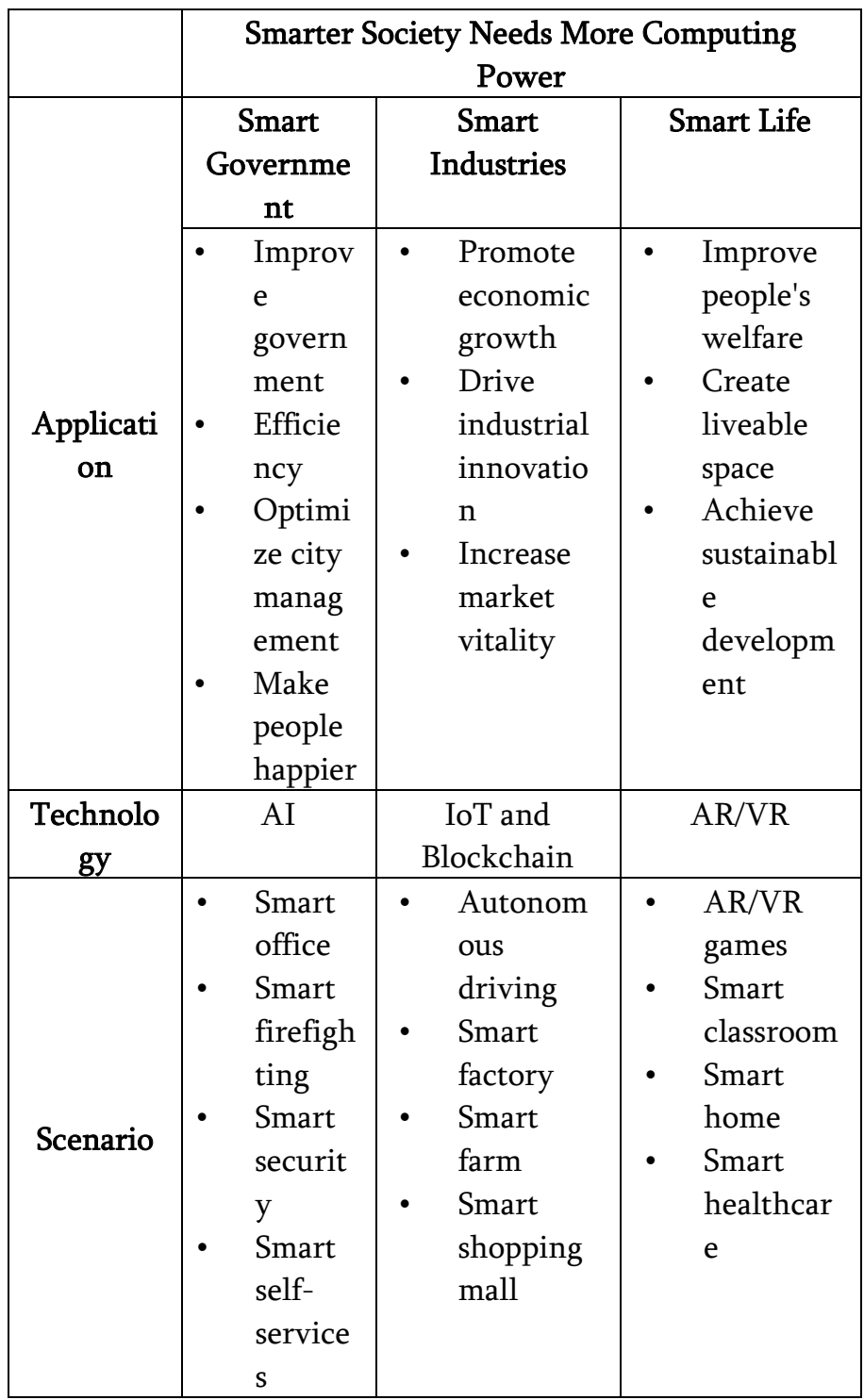

Source: Reproduce from [7]

In order to understand the 'bigger picture' of what is it all about in the ubiquitous information society and what may be happening in the future, a broader framework is needed. In the figure 1 a general evolutionary scheme of the big waves of technological and societal changes is presented. Names of the different eras in figure 1 are based on dominating or labelling technologies of each epoch. There are three important features pointed out by [10] in regard to societal change. First, the pace of change in development is intensifying. Second important characteristic is a tendency towards growth or rise of levels. The third and perhaps the most important feature in this evolutionary framework, is emergence. Significant technological changes bring quite new emergent features to the society, to its economy, consumption patterns and societal innovations. The prediction of an urban rise in population $(70 \%$ by 2050) has led to the emergence of smart cities [6].

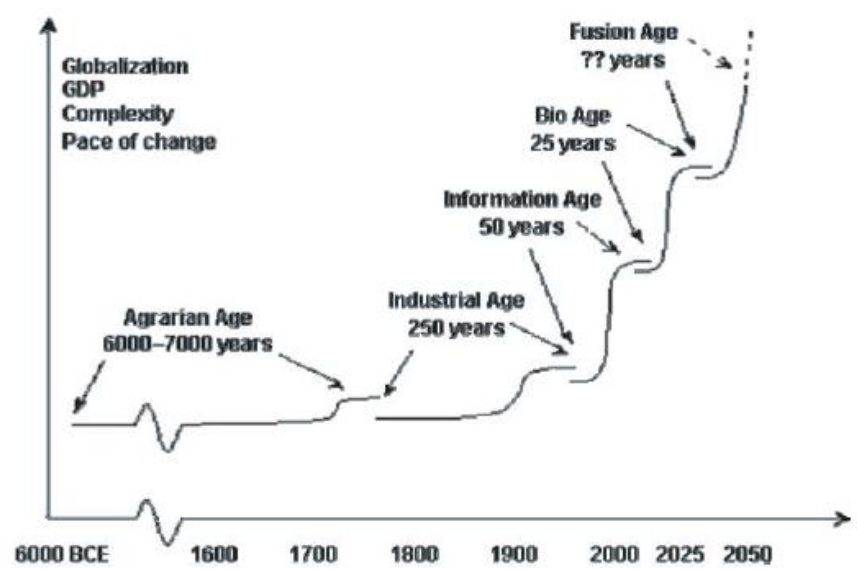

Figure 1. Big waves of Societal change Source: [6]

\section{Nigeria's ICT Revolution}

Information Communication Technology presents copious opportunities for the creation of unprecedented wealth for Nigeria. Nigeria has progressed from the information dark ages before the year 2000, to ICT revolution that is opening up new possibilities and frontiers across our business, political, social and economic landscape. Today, owing to several factors including government deregulation policy, the worldwide trend of rapid development in telecommunications and information technology and the huge potential of the Nigerian market, the story is very different. Since year 2000, Nigeria Communication Commission (NCC) has licensed Digital mobile Service providers, several Private Telephone Operators, Fixed wireless Access Operators, two Long Distance Operators, Internet Service Providers and a Second National Carrier [12]. 
According to [15], the Nigerian telecoms sector has shown to have grown to contribute $10.6 \%$ to GDP, driven largely by four major Mobile Network Operators (MNOs) who provide services to over 99.5\% of 184.7 Million active lines (NCC, 2019) with 126 Million of those lines (68\%), connected to the Internet $(2 \mathrm{G}+/ 3 \mathrm{G} / 4 \mathrm{G})$.

This activity has increased and promoted competition in the industry, resulting in exponential growth in the number of telephone lines (both mobile and fixed). Internet services are becoming available even on mobile phones, tablets, Ipads etc, making it possible to transact a wide range of services formerly available using a computer device only. Fixed and mobile wireless systems offer key advantages in making broadband and Internet services universally available because of the speed of deployment. Fast deployment means quicker connections to subscribers resulting in faster payback of capital investment. By these, all facet of the Nigeria ubiquitous society have revolutionize with new innovations, new approaches, new businesses, new life style, new taste, new direction and development.

Figure 2 depicts a scenario with situational trend in the Nigeria telecom business. The Mobile (GSM) statistics dominates Mobile (CMDA)

FixedWired/Wireless and VoIP lines for the three consecutive years that was considered. Yet, mobile CDMA technology has greater advantages with enhanced facilities proven to offer its users. Many business oriented outlets are quite embedded in the $4 \mathrm{G}$ technology which many people are unaware of, thereby, requiring that enlightenment and encouragement would be necessary to woo business owners to migrate for their benefits and ease of service provision to their customers.

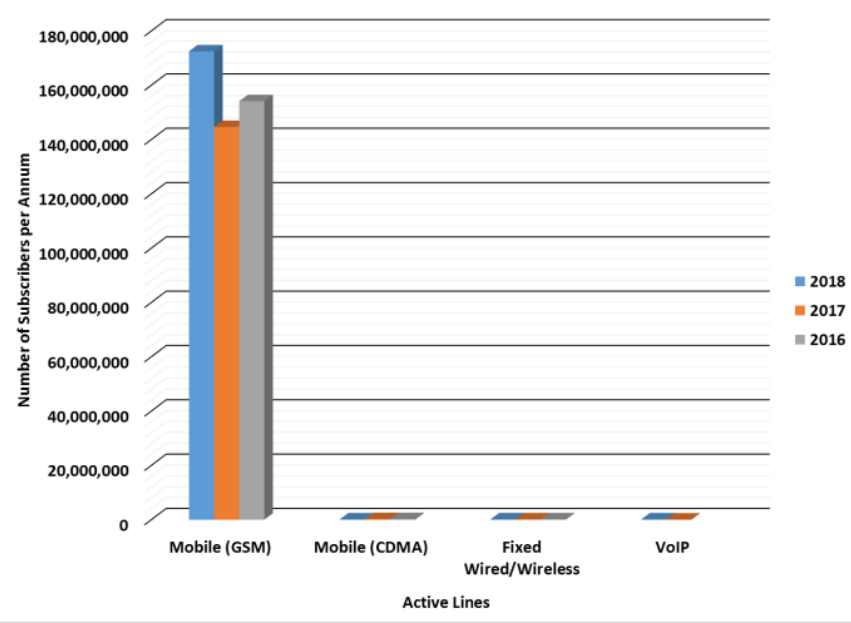

Figure 2: Nigeria Annual Subscriber Technology Data Source: [14]

\section{ICT AND SUSTAINABILITY}

Nigeria stands to gain in an effort geared toward massive drive in ICT infrastructure provision and a conscious attempt to ensure sustainability. For ICT to be sustainable, communication technologies must be accepted as a basic necessity of life with the existence of a clear value proposition. By clear value we mean the worth, importance and usefulness of ICT to socioeconomic development in a ubiquitous society. Until we make the value of ICT as self-evident as demand driven, we may not succeed in creating a society that values ubiquitous access to ICT. More over, the success of Nigeria national efforts and the works of international partnerships lie in good governance, driven by investments in ICTs, and shaped by the ability of the Nigerian governments to combat corruption, promote the rule of law and invest in her people. The additional ingredients necessary to make this happen are political will, effective public-private partnerships and demonstration of commitment by all stakeholders [2].

ICT sustainability must be born on some developmental objectives. First is to ensure achieving ICT availability, affordability and reliability in the current status of implementation. Secondly, ensuring 
that present infrastructure are robust and meets standard for operational integration as well as building additional up-to-date modern ICT infrastructure to existing ones, for the purpose of expansion. Thirdly, ensuring that protection, restoration and maintenance of existing infrastructure for system functionality and continuity of services to the targeted people. And fourthly, ensuring that adequate security for the infrastructure and its environs (communities) so as to provide an uninterrupted supply of service as well as tranquillity for the service use and its users.

\section{ICT and Economic Development}

The use of ICT is perceived as a catalyst for economic growth. Economic growth is the increasing ability of a nation to produce more goods and services. The use of ICT therefore enables the production of goods in a short amount of time with the aid of computer and its associated device. Services are also provided more efficiently and rapidly. Over the past decades, we have witnessed how the US economy has been revived in the late 1990s due to large investment in ICT. Through the deployment of ICT, the US and some EU member states as well as Japan and China have recorded resurgence of economic growth and of productivity, declining inflation and diminishing unemployment through the deployment of ICT [3]. There are indications that in Poland, ICT investment contributed on average 0.47 of a percentage point or $8.9 \%$ of GDP growth and $12.7 \%$ or 0.65 of a percentage point contribution to labour productivity between 1995 and 2000 [9].

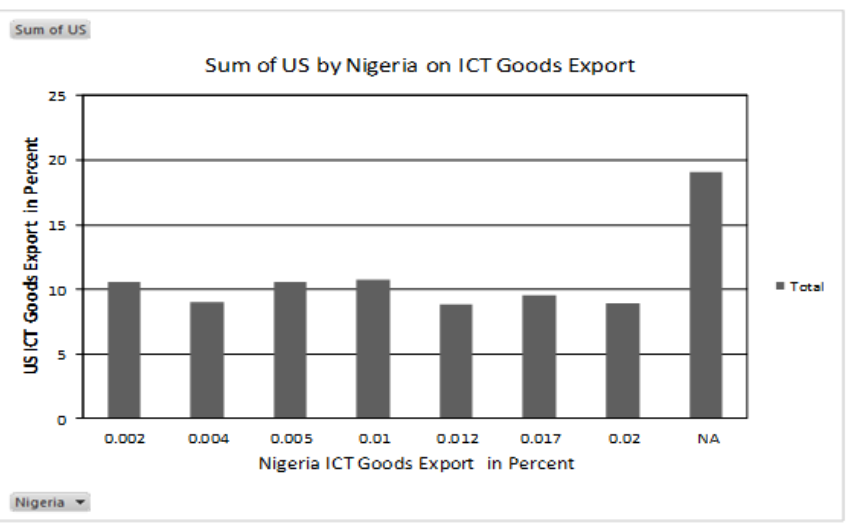

Figure 3: ICT goods export as a percentage of total goods export from 2008 to 2016 Source: [27]

The results on figure3 clearly demonstrate that as the contribution of ICT increases, the real output growth increases proportionately. There is a clear indication that Nigeria's ICT export for ICT has been dwindling since 2010 as compared to other developed countries represented in figure 3 . This has had a significant effect on the Nigeria economy [27]. In simple term, we could say that ICT drives the economy. Therefore, effective ICT investments will have a positive impact on any nation economy like Nigeria by helping her to leapfrog into the circle of the world's informationrich economies. This is validated by Isa Pantami, Nigeria's communications minister, that the country's information and communication technology sector contributed $13.9 \%$ to the country's GDP, while the oil and gas sector contributed just $8.8 \%$. Although, experts recommend comparing only real GDP figures, meaning that ICT sector actually contributed $14.6 \%$ to Nigeria GDP [1]. Figure 4 depict ICT sector as share of GDP and contribution to Nigeria economic growt for the year 2016 to the first quarter of 2020. It favours a steady growth between 2017 and 2018 and then began to experience decline in the fourth quarter of 2018 till 2020. It is an evidence of problems that were not immediately arrested by government agency and key players in the ICT industry. However, it must be stated clearly that an indicator of ICT positive impact on the economy cannot be overemphasised. 


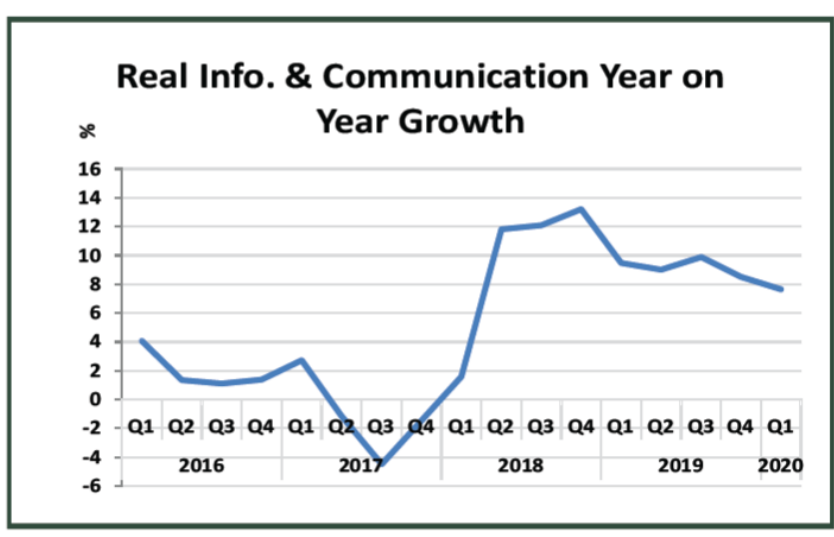

Figure 4: ICT Growth and contribution to Nigeria GDP Source: [22]

\section{ICT and Human Development}

Women Empowerment: women and communities that may be isolated by virtue of their geographical remoteness or other factors can be brought closer. ICT plays an important role in informing women about the risks and benefits of available care. Awareness campaigns can be launched through mass media outlets, such as the radio, television and internet. The internet in particular can provide women access to the latest information and best practices on a regular basis, by so doing bringing development to the women folks and communities at large.

Job Creation: ICT creates new jobs and entrepreneurial opportunities. Examples include the development, provision, and servicing of ICT equipment and services. By overcoming the cost of distance, Nigeria can be successful in creating completely new ICT-based industries, such as call centres and the software sector. The emergence of ICT has led to improvements in efficiency and productivity people daily outputs, reduction in transaction costs, increased service innovation and better quality of life. Over 10,000 persons have been recorded as directly employed by the GSM operators (ICT facilitators) and an estimated 10,000,000 Nigerians are said to be benefiting from indirect employment generated by the GSM operators. Indirect employment has also been created through contract awards to construction firms, research companies and media consultants. In the financial sector, enterprising banks have designed innovative products that leverage the use of GSM (Ndukwe, 2006).

In their work [8] showed that between 1999 and 2003 an asymptotic growth of both subscriber's lines and teledensity - a measure of telephone lines availability, was observed. Between 2003 and 2019, a positive steady steep growth was experienced; signally that usage is on the increase as indicated in figure 5.

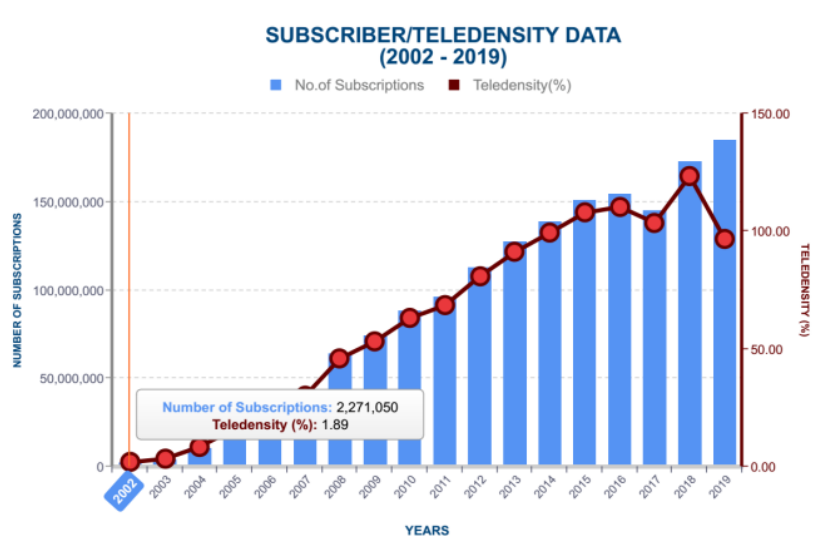

Figure 5: Subscriber Base and Teledensity Profile Source: [14]

Similarly, as indicated in figure 6, [5] showed the capability of ICT in job creation between 2004 and 2009. Each ICT component, that is, IT Hardware, Software, IT services and Channels gave good percentage indication for employment potentiality. 


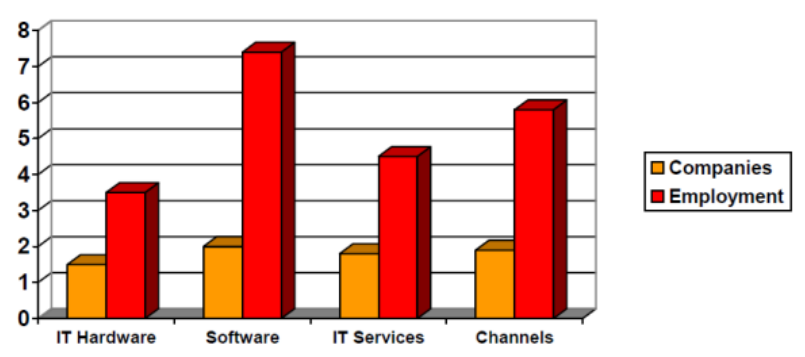

Figure 6: World ICT Job Creation Source: [5]

Monitoring: ICT facilitates the monitoring of public expenditures and supports political empowerment. By computerizing public expenditure tracking systems the monitoring of financial flows can be improved. This is of course particularly important for poor countries that require increased development assistance to meet national goals and donor agencies earmark targets. ICT can easily monitor levels of resources, such as inventory and personnel, to anticipate resource gaps. For example, continuous, real-time monitoring of inventory through ICT can immediately alert managers when supplies fall below critical thresholds. These thresholds could be fixed or linked via information networks to other systems, such as malaria surveillance systems, to estimate needs - in this case, anti-malarial drugs - for pregnant women under changing conditions. Also, ICT can link different providers together to increase coordination. In some areas, many different NGOs and government work alongside one another but find it difficult to track each other's activities, which could lead to duplicated efforts or supply shortages [4].

Health: ICT can create virtual links (telemedicine) between birth attendants and more highly trained personnel at district and referral hospitals. Mobile phones, radio units and digital cameras can all serve to enhance the quality of first-line care and improve referral capacity. Geographic Information Systems, a powerful ICT tool, helps planners visualize and integrate different layers of spatial data. Through GIS programs, maps can be created that integrate spatial data points (e.g., villages, roads, health facilities) with attributes about those points (e.g., population size of villages, ratios of skilled birth attendants to population, number of obstetricians at health facilities, etc.). GIS can help planners ensure that health workers are deployed in sufficient numbers to the places that need them [4]. Using ICTs for health development is not new. Mapping for infectious diseases such as HIV/AIDS, Tuberculosis (TB), Sexually Transmitted Infections (STIs) and malaria allow clinicians and policy makers to plan for influx and understand trends. Health information systems allow clinics to follow up and track patients and their histories over time. ICTs are useful in both broad and targeted health communication campaigns for behaviour change and information sharing. Of course to benefit from these initiatives, the intended audience must have access to ICTs facilities and networks to enable all facets of health care services.

Efficiency: ICT can increase the efficiency of social service delivery and raise economic productivity. For example, computer-based procurement systems have been shown to dramatically reduce costs in the health sector. Likewise, modern information technologies has been proved to reduce the cost of doing business by raising productivity and lowering the cost of market entry. ICT networks can improve physical links by expediting the response of emergency transportation. ICT create virtual link -Telemedicine - between birth attendants and more highly trained personnel at district and referral hospitals. Mobile phones, radio units and digital cameras can all serve to enhance the quality of first-line care and improve referral capacity. When women are moved to different levels of health system for care, communication networks and integrated, electronic patient data systems can also help secure continuity of care. 


\section{ICT and Social Development}

ICT can help to facilitate free flow of information (thereby supporting democratization of narrowminded societies) and lead to increased transparency of the Government operations through e-Government initiatives. It can help to provide logistic support when disasters strike whether they are natural (such as cyclones, earthquakes, volcanic activity, etc.) or man-made disasters (such as oil spills, fire or nuclear accidents). ICT, especially the internet, creates networks through which individuals can share values and experiences - as in social network. This sharing might relax certain cultural norms that decrease health seeking behaviour as well as strengthen cultural practices that encourage health seeking behaviour or create national forum for national debate on government policies affecting the populace. ICT adoption would naturally adopt the four way precept of knowledge, Quality, Infrastructure provision and affordability to all as shown in figure 7 below.

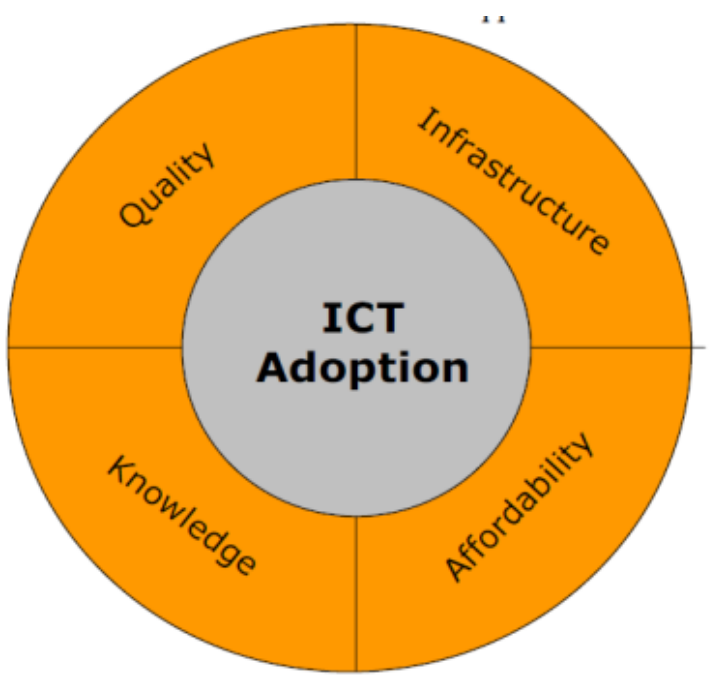

Figure 7 : Actions focused on the Adoption of ICT Source : [5]

\section{ICT and Infrastructure Development}

Government and Private organizations have already recognized the need for ICT infrastructure to be put in place and also be made competitive in a networked economy in order to speed up development. Businesses cannot effectively operate where reliable high-speed communications networks and associated technical support infrastructure are not available [25]. Cities have responded in some places with publicly financed wired and wireless broadband infrastructure projects. It is clear based on our research that local governments have a legitimate interest in ensuring that basic services are generally available and reasonably affordable.

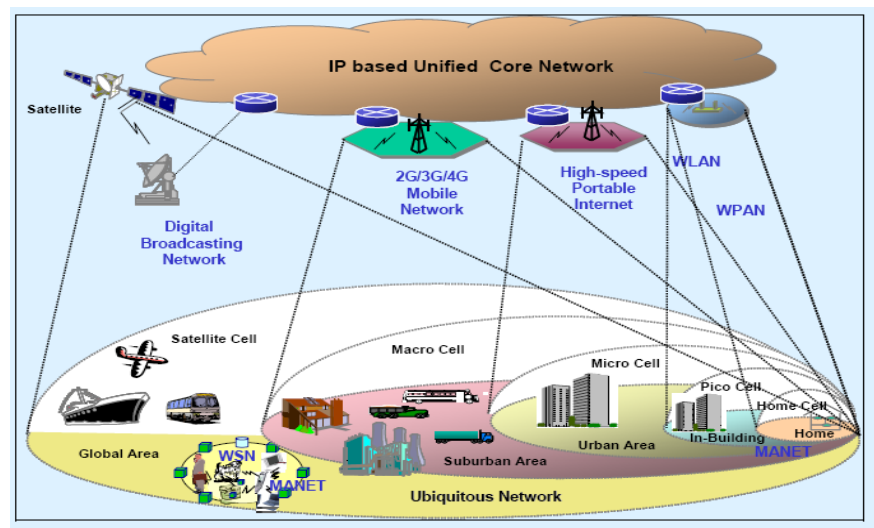

Figure 8: Hierarchical Structure of Mobile Wireless Network Infrastructure Source : [21]

The mobile wireless network infrastructure organized into a cell hierarchy as shown in figure 8 is based on the technology that is already deployed and can be used for varied human activities. Starting from the home cell with coverage in private buildings such as a house or office to public hotspot locations such as airport, train station, conference centre, and service centre, remote and rural locations may be provided through an access point. In a hierarchical multilayered cell environments, extra intelligence is required so that the network can find a specific terminal or the terminal can determine the boundaries between wireless networks and switch to the most appropriate one. In addition, the evolution to all-IP networks in mobile communication to enable the ICT services that can operate in different 
networks will become an important issue for the future broadband mobile communications and the development of the Internet [21] in Nigeria Socioeconomic system.

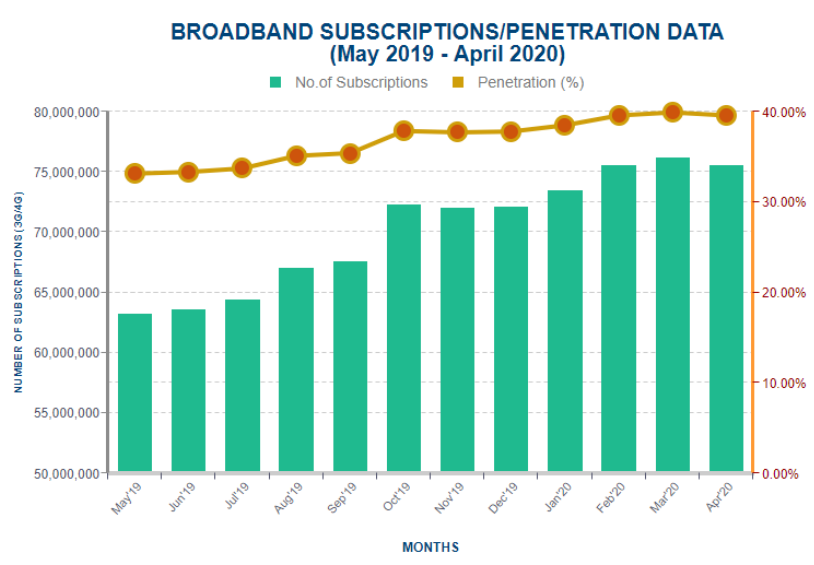

Figure 9: Coverage of Infrastructure Development over a period Source: [14]

In figure 9, [8] showed the extent of telecommunication infrastructural development in Nigeria between 2006 and 2008. In 2008, Fibre optic had small coverage and is being trailed by Base Station infrastructure. Distance coverage for Microwave Radio showed greatest expansion than all the other two. We believe that if the trends of developments continue, we are sure to witness sufficient and complete coverage over the Nigeria geographic terrains.

\section{POLICY AND REGULATION}

Clearly the policy frameworks and various regulations that are now in force (e.g., data protection, anti-spam) are necessary step toward ubiquitous network societies, but are they sufficient to realize the fullness of the vision? What impact might new policy initiatives, such as the U-Japan Strategy, have on trans-border data flows and the international context of information systems and practices? Will new institutions need to be established, or are the current international bodies suited to the demands of the foreseeable future?

The current framework for regulation of ICTs in Nigeria is illustrated in Figure 10. If the draft National ICT Policy of 2012 is approved, the government would merge the broadcasting and telecommunications regulators (the NBC and NCC) into a single body with sweeping powers under a new regulatory framework [16].

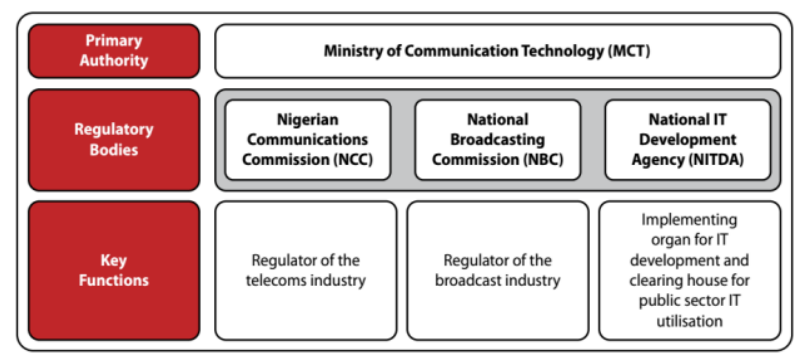

Figure 10 : Current framework for ICT regulation in Nigeria Source: [16]

\section{ICT Road Map}

The road map to ICT development is the convergence of ICT products and services that would bring a number of opportunities for the country economic and social development in a virile ubiquitous society. Here are some road maps as viewed by [13], [28] and others we have equally conceived.

(1) Economic Development, including:

a) Increasing business productivity by reducing the cost of communications, cost of data storage and data processing.

i. Enabling new ways of working, such as teleworking and video conferencing

ii. Enabling new types of enterprise, such as online business

b) Providing software products that can reduce bribery and corruption thereby facilitating good governance 
c) Establishing policies that integrate local contents on ICT adoption in all government transactions.

The degree to which these benefits are achieved will depend greatly on how well policy makers and regulators respond to the challenges of convergence.

(2) Bribery and Corruption, including:

a) Large-scale corruption involving large sums of money but very small numbers of people, such as during privatisation or large equipment contracts;

b) Endemic business corruption and small-scale corruption, where bribes or corrupt practices are simply part of a wider corruption culture in the country concerned; and

c) Small-scale corruption that involves paying someone off to get something done, such as paying a bribe to get a phone installed or official document processing and etc.

(3) Intellectual Property Rights (IPR):

Providing satisfactory protection from misuse of materials or creation of inappropriate contents by way of establishing national and international legislations to contain illegitimate practices by ICTs practitioners and vendors, and thereby reducing piracy and counterfeits. Piracy is creating hard nut to crack for Internet and Software companies, with host of counterfeit products posing additional challenges.

\section{(4) Creation of Smart Society.}

The existing structure of ICT enabled by broadband technology infrastructure will bring to bear the creation of smart society.

\section{III.CONCLUSION}

For Nigeria to be a competitive and innovative society that ensures the wellbeing for everyone, ICT must be stimulated. To achieve this, we must first of all get ICT back on the political programme with a view to prioritising deployment of ICT infrastructure related components. Productivity gains can only be achieved throughout the whole of society by using ICT, and by constantly emphasising its importance and potential. Market conditions, regulatory and enabling environment that will encourage the introduction and use of innovations, new services and new business models are to be encouraged.

\section{REFERENCES}

[1]. Africa Check, "ICT outstrips oil and gas in Nigeria's economy - but error in minister's comparison," Accessed on June 2020 from https://africacheck.org/reports/informationtechnology-outstrips-oil-and-gas-in-nigeriaseconomy-but-error-in-ministers-comparison, 2019.

[2]. R. C. Carlos. "Executive Summary. ICT for Education and Development." In The Challenges of meeting the Millennium Development Goals in Africa." CIDJAP Publishers Ltd. Enugu, Nigeria. Accessed from http://citeseerx.ist.psu.edu/viewdoc/download?d oi=10.1.1.96.6873 \&rep=rep 1\&type=pdf, 2020.

[3]. Commission of European Community. "The Impact of the e-economy on European Enterprises: Economic Analysis and Policy Implications." Communication from the Commission to the Council and the European Parliament. Brussels, 2001.

[4]. G. Conille and B. Lutz. "MDG5: Maternal health.” In ICT for Education and Development. The Challenges of meeting the Millennium Development Goals in Africa. CIDJAP Publishers Ltd. Enugu, Nigeria, Accessed from http://citeseerx.ist.psu.edu/viewdoc /download?doi=10.1.1.96.6873\&rep=rep 1\&type=pdf, 2020 . 
[5]. C. Feijóo, J. L. Gómez-Barroso and A. Martín. "Software Opportunities." In ICT for Education and Development. The Challenges of meeting the Millennium Development Goals in Africa. CIDJAP Publishers Ltd. Enugu, Nigeria. Accessed from http://citeseerx.ist.psu. edu/viewdoc $\quad /$ download?doi=10.1.1.96.6873 \&rep=rep 1\&type=pdf, 2020.

[6]. K. Fernando, M. Felipe and L. Kiran. "Agent Technology for Intelligent Mobile Services and Smart Societies." Springer Heidelberg, New York Dordrecht London, 2015.

[7]. Huawei (2020). Ubiquitous Computing Power: the Cornerstone of an Intelligent Society. Position Paper,"accessed from https://wwwfile.huawei.com/-/media/corporate/pdf/publicpolicy/

ubiquitous_computing_power_the_cornerstone _intelligent_society_en.pdf?la=en, 2020.

[8]. A. B. Ikharo, A. M. Arasomwan and C. O. Omeiza. "Deploying Broadband Mobile Communication Networks to Facilitate General Election in Nigeria." International Journal of Computer Science. IJCOMS -2010 -150, 2010.

[9]. T. Kanamori. "Contribution of ICT to Economic Growth in Asia." ITS 15th Biennial Conference, Berlin, Germany, 2004

[10]. M. Mannermaa. "Living in the European Ubiquitous Society." Journal of Futures Studies, 11(4): 105 - 120, 2006.

[11]. M. Matsumoto, T. Tamura and J. Fujimoto. "Prospects for an environmentally sustainable ICT society." Research Project of Japan Low Carbon Society supported by Ministry of the Environment, Japan, 2006.

[12]. E. Ndukwe. "The Expansion of Telecommunications." In ICT for Education and Development. Accessed from http://citeseerx.ist.psu. edu/viewdoc /download?doi= $\quad 10.1 .1 .96 .6873 \quad \&$ rep=rep 1\&type=pdf, 2020 .
[13]. L. Neves. "The Contribution the ICT Industry Can Make to Sustainable Development: A Materiality Assessment by the Global eSustainability Initiative." Prepared by Business for Social Responsibility (BSR), 2008.

[14]. Nigerian Communication Commission. "Industry statistics." Retreived on 24 May 2020 from ww.ncc.gov.ng/stakeholder/statisticsreports/industry-overview\#annual-2002-2018, 2020.

[15]. Nigerian National Broadband Plan 2020 - 2025 (2020). Accessed June 2020 from https://www.ncc.gov.ng/accessible/documents/8 80-nigerian-national-broadband-plan-20202025/file.

[16]. F. Odufuwa. "What is happening in ICT in Nigeria - A supply- and demand-side analysis of the ICT sector." Research ICT Africa.net, 2012.

[17]. J. E. Ogbuabor, M. N. Agu and U. I. Kalu. "The social Impacts of Information and Communication Technology in Nigeria." International Journal of Economics and Financial Issues, 2017, 7(2), 524-529, 2017.

[18]. M. O. Okoye. "Social Implications of ICTs: Views of Academic Librarians in Nigeria." Library Philosophy and Practice (e-journal). 821.

https://digitalcommons.unl.edu/libphilprac/821? utm_source=

digitalcommons.unl.edu\%2Flibphilprac\%2F821 \&utm_medium=PDF\&utm_campaign=PDFCove rPages, 2012.

[19]. R. Reddy, V. S. Arunachalam, R. Tongia, E. Subrahmanian and N. Balakrishnan. "Sustainable ICT for Emerging Economies Mythology and Reality of the Digital Divide Problem." A Discussion Note. Allied Publisher Pvt Ltd, Bangalore, India, 2004.

[20]. G. Schmidt-Traub. "Meeting the Millennium Development Goals and the role for ICT." In ICT for Education and Development: The 
Challenges of meeting the Millennium Development Goals in Africa. CIDJAP Publishers Ltd. Enugu, Nigeria, 2006.

[21]. L. Srivastava and T. Kelly. "Broadband Mobile Communications Towards a Converged World Emerging Technology Scenario: What are the Future Broadband Mobile Services?" ITU/MIC Workshop on Shaping the Future Mobile Information Society. SMIS/05, 2004.

[22]. Technext.ng. "NBS Report: ICT contribution to Nigeria's real GDP drops to N1.28 trillion in Q1 2020." Access June 2020 from https://technext.ng/2020/06/01/nbs-report-ictcontribution-to-nigerias-real-gdp-drops-to-n128-trillion-in-q1-2020/, 2020.

[23]. H. C. Ukwuoma. "The Effect of ICT on Economic Growth in Nigeria." International Journal of Management, Technology and Engineering Volume IX, Issue II pp 2249-7455, 2019.

[24]. United Nation Commission for Science and Technology Development. "ICTs for Inclusive Social and Economic Development." 2013-2014 Intersessional Panel, Washington DC, 2013.

[25]. W. Wagener. "Connected and Sustainable ICT Infrastructure." A White Paper for the Connected Urban Development Global Conference, Amsterdam, 2008.

[26]. www.brooking.edu. Accessed on 22nd May 2020 from https://www.brookings.edu/research /enabling-opportunities-5g-the-internet-ofthings-and-communities-of-color/, 2020.

[27]. H. C. Ukwuoma. "The Effect of ICT on Economic Growth in Nigeria" International Journal of Management, Technology And Engineering. Accessed on June 2020 from https://www.researchgate.net/publication/33190 3032, 2019.

[28]. The 2017 edition of the Measuring the Information Society Report was launched during the World Telecommunication/ICT
Indicators Symposium (WTIS) 2017, in Hammamet, Tunisia. Access June 2020

\section{Cite this article as :}

Ikharo A. B., Aliu D., Obasi C. C., Okreghe C. O., "ICT: Providing Sustainable Economic and Social Development in a Ubiquitous Network Society", International Journal of Scientific Research in Science and Technology (IJSRST), Online ISSN : 2395-602X, Print ISSN : 2395-6011, Volume 7 Issue 4, pp. 12-24, July-August 2020. Available at doi : https://doi.org/10.32628/IJSRST207389 Journal URL : http://ijsrst.com/IJSRST207389

\section{at}

